\title{
Percutaneous Transhepatic and Transsplenic Portal Vein Access: Embolization of the Puncture Tract Using Amplatzer Vascular Plugs
}

\section{Perkutaner transhepatischer und transsplenischer Pfortaderzugang: Embolisation des Punktionskanales mittels Amplatzer Vascular Plugs}

Authors

Affiliation
M. Dollinger, H. Goessmann, R. Mueller-Wille, W. A. Wohlgemuth, C. Stroszczynski, P. Heiss

Institute of Radiology, University Hospital Regensburg
Key words

- percutaneous transhepatic and transsplenic portal vein access

- puncture tract embolization - Amplatzer Vascular Plug received $\quad 13.3 .2013$ accepted 24.7.2013

Bibliography

Dol http://dx.doi.org/

10.1055/s-0033-1350514

Published online: 14.10.2013

Fortschr Röntgenstr 2014; 186 : 142-150 @ Georg Thieme

Verlag KG Stuttgart · New York . ISSN 1438-9029

\section{Correspondence}

Dr. Marco Dollinger

Institut für Röntgendiagnostik, Universitätsklinikum

Regensburg

Franz-Josef-Strauß-Allee 11

93053 Regensburg

Germany

Tel.: ++ 49/0941/9447401

Fax: ++49/0941/9447402

marco.dollinger@ukr.de

\section{Zusammenfassung}

$\nabla$

Ziel: Wir berichten über erste Ergebnisse der Embolisation transhepatischer und transsplenischer Zugangswege zur Pfortader mittels Amplatzer Vascular Plugs (AVP).

Material und Methoden: Bei fünf Patienten wurde eine Embolisation des transhepatischen und transsplenischen Punktionskanales mittels AVP angestrebt (3 weiblich; Alter: 3-71 Jahre). Der Zugang zur Pfortader erfolgte in vier Fällen transhepatisch, in einem Fall transsplenisch. Über diese perkutanen Zugänge wurden erfolgreich Stenosen $(n=2)$ bzw. Thrombosen $(n=3)$ der Pfortader mittels perkutaner Stentangioplastie oder Thrombusaspiration und Thrombolyse unter Verwendung von 6- bis 10-French-Schleusen behandelt. Aufgrund relativer großer und/oder kurzer transparenchymaler Punktionskanäle wurde es als günstig erachtet, den Punktionskanal mittels AVP zu embolisieren. Die Krankenakten, Interventionsprotokolle sowie Röntgenbilder dieser fünf Patienten wurden retrospektiv ausgewertet. Ergebnisse: In drei Fällen wurden je ein AVP II (Durchmesser: $4 \mathrm{~mm}$ ), in einem Fall ein AVP IV (Durchmesser: $4 \mathrm{~mm}$ ) und in einem Fall zwei AVPs II (Durchmesser: 8 und $6 \mathrm{~mm}$ ) zur Embolisation des Punktionskanales eingebracht. In allen fünf Fällen war die Embolisation erfolgreich, im Besonderen trat keine Nachblutung aus dem Punktionskanal auf. Während eines medianen Beobachtungszeitraumes von 14 Monaten (Spanne: 21 Tage bis 21 Monate) entwickelte eine Patientin einen an den AVP angrenzenden, fokalen Leberabszess, welcher mittels Antibiose und Drainagenanlage erfolgreich therapiert wurde. Es traten keine weiteren Komplikationen im Zusammenhang mit der Embolisation des Punktionskanales auf.

Schlussfolgerungen: AVPs sind geeignet, um großkalibrige und/oder kurze transhepatische und transsplenische Punktionskanäle effektiv und sicher zu embolisieren. Vorsicht ist geboten bei Pa-

\section{Abstract \\ $\nabla$}

Purpose: To report on first results of the embolization of transhepatic and transsplenic puncture tracts using an Amplatzer Vascular Plug (AVP) after percutaneous portal vein intervention.

Materials and Methods: Embolization of transhepatic and transsplenic puncture tracts with AVP was attempted in 5 patients ( 3 females; age range: $3-71$ years). Portal vein access was gained by a transhepatic $(n=4)$ or transsplenic $(n=1)$ approach, and stenosis $(\mathrm{n}=2)$ or thrombosis $(n=3)$ of the portal vein was successfully treated by percutaneous stenting or thrombus aspiration and thrombolysis using 6 to 10 French sheaths. Due to the relatively large bore and/or short transparenchymal puncture tracts, it was considered favorable to use AVPs as an embolic agent. The medical records, the radiological reports and images of these 5 patients were retrospectively evaluated.

Result: In three cases one AVP II (diameter, $4 \mathrm{~mm}$ ), in one case one AVP IV (diameter, $4 \mathrm{~mm}$ ) and in one case two AVPs II (diameter, 8 and $6 \mathrm{~mm}$ ) were used for embolization of the puncture tract. In all five cases embolization was technically successful. There was no bleeding from the puncture tract. During a median follow-up of 14 months (range, 21 days to 21 months), one patient developed a focal liver abscess adjacent to the AVP which was successfully treated by antimicrobial and drainage therapy. There were no further embolization-related complications.

Conclusion: AVPs are suited to embolize large bore and/or short transhepatic and transsplenic puncture tracts effectively, safely, and precisely. Caution is required in patients with an increased risk for infectious complications.

Key Points:

- Embolization of transhepatic and transsplenic puncture tracts with AVPs is feasible 
tienten mit einem erhöhten Risiko für infektiöse Komplikationen. Kernaussagen:

- Embolisation transhepatischer sowie transsplenischer Punktionskanäle mittels AVPs ist durchführbar

- Große und/oder kurze Punktionskanäle können effektiv mittels AVPs embolisiert werden

- Das Risiko infektiöser Komplikationen muss beachtet werden
- Large and/or short puncture tracts can be effectively embolized with AVPs

- The risk of infectious complications has to be considered

Citation Format:

- Dollinger M, Goessmann H, Mueller-Wille R etal. Percutaneous Transhepatic and Transsplenic Portal Vein Access: Embolization of the Puncture Tract Using Amplatzer Vascular Plugs. Fortschr Röntgenstr 2014; 186: 142-150

\section{Introduction}

Percutaneous puncture of an intrahepatic portal or intrasplenic vein is an option for accessing the portal vein, e.g. in order to treat portal vein stenosis or thrombosis $[1-8]$. After the intervention removal of the inserted catheter or sheath can result in significant bleeding from the puncture tract which might necessitate emergent surgery. Embolization of the transparenchymal puncture tract using various embolic agents including collagen, coils, Gelfoam, and N-butyl cyanoacrylate has been described [1-8].

The purpose of the present study was to report on first results of embolization of large bore and/or short transhepatic and transsplenic puncture tracts using Amplatzer Vascular Plugs (AVP).

\section{Patients and Methods}

$\nabla$

\section{Patients}

The Independent Ethics Committee at the University Medical Center of Regensburg confirmed that according to the state law for retrospective studies such as this, ethics approval or the committee's opinion is not necessary.

In February 2011 we started to use AVPs (AGA Medical Corp., North Plymouth, Minnesota, USA) for the embolization of transhepatic and transsplenic puncture tracts. All patients in whom embolization of those transhepatic or transsplenic puncture tracts with AVP was attempted were retrospectively analyzed. Embolization with an AVP was attempted in 5 patients ( 3 females; age range: $3-71$ years). The medical records as well as the radiological reports and images of these patients were evaluated.

Patient characteristics are presented in 0 Table 1. Two patients (patients \# 1 and \# 2) presented with stenosis and three patients (patients \# 3-5) with thrombosis of the portal vein. It was decided to treat these conditions by a percutaneous transhepatic or transsplenic approach in interdisciplinary consensus. Written informed consent was obtained from the patients and the parents of patient \# 5.

\section{Portal vein intervention}

Based on the findings of contrast-enhanced computed tomography of the abdomen which was performed prior to each intervention, it was decided to access the portal vein by a transhepatic and a transsplenic approach in four patients (patients \# 1 - 4) and one patient (patient \# 5), respectively. In the latter case (patient \# 5), computed tomography displayed extensive thrombosis of the splenic vein as well as some thrombi within the portal vein (৫ Fig. 1). In this patient a left-lateral-segment liver graft was implanted orthotopically. The course of the extrahepatic portal vein took a 145 degree curve to the left ( $\bullet$ Fig. 1b). Hence, it was determined that thrombus aspiration via a transsplenic access was more suitable than via a transhepatic access.
In each patient an attempt was made to puncture a peripheral branch of the right portal vein or a peripheral intrasplenic vein about $2-3 \mathrm{~cm}$ (in children $1-1.5 \mathrm{~cm}$ ) central to the liver or spleen capsule under sonographic guidance using a 21-gauge needle (CHIBA, Boston Scientific, Natick, MA, USA). A guide wire was advanced into the portal or splenic vein, and, using an AccuStick introducer system (Boston Scientific, Natick, MA, USA), a sheath was inserted in the Seldinger technique.

In two patients (patients \# 1 and \#2) stenting of a portal vein stenosis was carried out ( $\bullet$ Table 1 ). In three patients (patients \# 3 -5) thrombus aspiration in combination with thrombolysis for five to eight days was performed. For these treatments 6 to 10 French sheaths were inserted ( $\bullet$ Table 1 ). In patients \# 1 and \# 25000 IU of heparin were administered peri-interventionally. In patients \# 3-5 thrombolysis was performed using urokinase (30 000 IU per hour) in combination with continuous heparin infusion (partial thromboplastin time, 80-100 s). Patient \# 5 was given aspirin ( $50 \mathrm{mg}$ per day) as well. In patients \# $3-5$ administration of urokinase and heparin was ceased for 2 hours prior to embolization of the puncture tract.

\section{Indication for use of AVP}

After treatment of the portal vein was completed, embolization of the transhepatic and transsplenic puncture tracts using an AVP was carried out by three operators with 3-15 years interventional radiology experience. Due to reported bleeding complications which emerged despite embolization of the puncture tracts using various embolic agents, the interventionists considered AVPs to be the most favorable agent for effective, safe and quick embolization of the relatively large bore puncture tracts in all five cases. In addition, in patient \# 5, a 3-year old boy, it was considered that the use of an AVP might allow embolization of the relatively short transsplenic puncture tract safely and precisely at a subcapsular site. According to the interventionists' preference, AVP II or AVP IV was used.

\section{Technique of puncture tract embolization.}

In three patients (patients \# $1, \# 3$, and \#5) the puncture tract was embolized by the same operator who attempted to place the AVP II within the puncture tract in the manner that the distance between the AVP and the hepatic or splenic capsule was $1.5 \mathrm{~cm}$ and $1 \mathrm{~cm}$ in adults and children, respectively ( $\bullet$ Fig. 1, 2). Embolization of patients \# 2 and \# 4 was performed by two other operators who attempted to place an AVP II or AVP IV in the middle portion of the puncture tract ( $\bullet$ Fig. 3,4 ). In three patients a stiff guide wire (patient \# 1, 0.014-inch PT2-wire, Boston Scientific Corporation, Natick, MA, USA, $\odot$ Fig. 2; patients \# 3 and \# 5, 0.035-inch Amplatz Guidewire, Boston Scientific Corporation, Natick, MA, USA, $\triangle$ Fig. 1) was placed in the portal vein as a lock wire in order to enable reinsertion of the sheath into the puncture tract in case the sheath accidentally dislocated from the puncture tract. 
Table 1 Clinical characteristics, data of percutaneous portal vein intervention and puncture tract embolization as well as outcome of five patients in whom the transhepatic or transsplenic puncture tract was embolized using Amplatzer Vascular Plugs (AVP) (mm, millimeters; h, hours; d, days; y, years; mg, milligram; $\mathrm{m}$, male; f, female).

Tab. 1 Klinische Charakteristika, Daten der perkutanen Pfortaderintervention und der Embolisation des Punktionskanales sowie des Outcomes von fünf Patienten, bei denen der transhepatische oder transsplenische Punktionskanal mittels Amplatzer Vascular Plugs (AVP) embolisiert wurde (mm, Millimeter; h, Stunden; d, Tage; $y$, Jahre; mg, Milligramm; m, männlich; f, weiblich).

\begin{tabular}{|c|c|c|c|c|c|c|c|c|c|c|c|}
\hline $\begin{array}{l}\text { patient } \\
\text { no. }\end{array}$ & $\begin{array}{l}\text { age } \\
\text { (y)/sex }\end{array}$ & $\begin{array}{l}\text { basic } \\
\text { disease }\end{array}$ & $\begin{array}{l}\text { previous } \\
\text { surgical } \\
\text { treatment }\end{array}$ & $\begin{array}{l}\text { indication } \\
\text { for portal } \\
\text { vein } \\
\text { access }\end{array}$ & access & $\begin{array}{l}\text { size of } \\
\text { sheath/ } \\
\text { duration } \\
\text { of } \\
\text { sheath } \\
\text { insertion }\end{array}$ & $\begin{array}{l}\text { percutaneous } \\
\text { portal vein } \\
\text { intervention }\end{array}$ & $\begin{array}{l}\text { type and } \\
\text { diame- } \\
\text { ter of } \\
\text { AVP }\end{array}$ & $\begin{array}{l}\text { success of } \\
\text { puncture } \\
\text { tract em- } \\
\text { bolization }\end{array}$ & $\begin{array}{l}\text { puncture } \\
\text { tract- } \\
\text { related } \\
\text { complica- } \\
\text { tions }\end{array}$ & follow-up \\
\hline 1 & $70 / f$ & $\begin{array}{l}\text { biliary } \\
\text { cirrhosis }\end{array}$ & $\begin{array}{l}\text { status post } \\
\text { liver trans- } \\
\text { plantation }\end{array}$ & $\begin{array}{l}\text { stenosis of } \\
\text { portal vein } \\
\text { anastomo- } \\
\text { sis }\end{array}$ & $\begin{array}{l}\text { trans- } \\
\text { hepatic }\end{array}$ & $\begin{array}{l}10 \\
\text { French } \\
2 \mathrm{~h}\end{array}$ & $\begin{array}{l}\text { stenting of por- } \\
\text { tal vein stenosis }\end{array}$ & $\begin{array}{l}\text { AVP II; } \\
4 \mathrm{~mm}\end{array}$ & yes & no & $\begin{array}{l}21 \text { months } \\
\text { during follow-up no } \\
\text { AVP/puncture tract- } \\
\text { related complica- } \\
\text { tions }\end{array}$ \\
\hline 2 & $47 / f$ & $\begin{array}{l}\text { mucinous } \\
\text { adenocarci- } \\
\text { noma of the } \\
\text { appendix }\end{array}$ & $\begin{array}{l}\text { status post } \\
\text { cytoreduc- } \\
\text { tive surgery }\end{array}$ & $\begin{array}{l}\text { stenosis of } \\
\text { portal vein } \\
\text { by tumor } \\
\text { compres- } \\
\text { sion }\end{array}$ & $\begin{array}{l}\text { trans- } \\
\text { hepatic }\end{array}$ & $\begin{array}{l}6 \text { French } \\
0.5 \mathrm{~h}\end{array}$ & $\begin{array}{l}\text { stenting of por- } \\
\text { tal vein stenosis }\end{array}$ & $\begin{array}{l}\text { AVP IV; } \\
4 \mathrm{~mm}\end{array}$ & yes & $\begin{array}{l}\text { liver } \\
\text { abscess }\end{array}$ & $\begin{array}{l}\text { died } 8 \text { months later } \\
\text { due to respiratory } \\
\text { insufficiency. Dur- } \\
\text { ing follow-up no fur- } \\
\text { ther AVP/puncture } \\
\text { tract-related com- } \\
\text { plications }\end{array}$ \\
\hline 3 & $71 / f$ & $\begin{array}{l}\text { necrotizing } \\
\text { pancreatitis }\end{array}$ & $\begin{array}{l}\text { status post } \\
\text { resection of } \\
\text { pancreatic } \\
\text { pseudocyst }\end{array}$ & $\begin{array}{l}\text { thrombo- } \\
\text { sis of por- } \\
\text { tal and } \\
\text { superior } \\
\text { mesen- } \\
\text { teric vein }\end{array}$ & $\begin{array}{l}\text { trans- } \\
\text { hepatic }\end{array}$ & $\begin{array}{l}8 \text { French } \\
5 \mathrm{~d}\end{array}$ & $\begin{array}{l}\text { thrombus } \\
\text { aspiration, } \\
\text { thrombolysis } \\
\text { with urokinase } \\
\text { and heparin }\end{array}$ & $\begin{array}{l}\text { AVP II; } \\
4 \mathrm{~mm}\end{array}$ & yes & no & $\begin{array}{l}14 \text { months } \\
\text { during follow-up no } \\
\text { AVP/puncture tract- } \\
\text { related complica- } \\
\text { tions }\end{array}$ \\
\hline 4 & $63 / \mathrm{m}$ & $\begin{array}{l}\text { hyperne- } \\
\text { phroma }\end{array}$ & $\begin{array}{l}\text { status post } \\
\text { nephrect- } \\
\text { omy ( } 10 \\
\text { years ago) }\end{array}$ & $\begin{array}{l}\text { extensive } \\
\text { thrombo- } \\
\text { sis of por- } \\
\text { tal vein }\end{array}$ & $\begin{array}{l}\text { trans- } \\
\text { hepatic }\end{array}$ & $\begin{array}{l}8 \text { French } \\
8 \mathrm{~d}\end{array}$ & $\begin{array}{l}\text { thrombus } \\
\text { aspiration, } \\
\text { thrombolysis } \\
\text { with urokinase } \\
\text { and heparin }\end{array}$ & $\begin{array}{l}\text { AVP II; } \\
6 \mathrm{~mm} \\
\text { and } \\
8 \mathrm{~mm}\end{array}$ & yes & no & $\begin{array}{l}14 \text { months } \\
\text { during follow-up no } \\
\text { AVP/puncture tract- } \\
\text { related complica- } \\
\text { tions }\end{array}$ \\
\hline 5 & $3 / \mathrm{m}$ & $\begin{array}{l}\text { biliary } \\
\text { atresia }\end{array}$ & $\begin{array}{l}\text { status post } \\
\text { liver trans- } \\
\text { plantation }\end{array}$ & $\begin{array}{l}\text { thrombo- } \\
\text { sis of sple- } \\
\text { nic and } \\
\text { portal vein }\end{array}$ & $\begin{array}{l}\text { trans- } \\
\text { splenic }\end{array}$ & $\begin{array}{l}8 \text { French } \\
5 \mathrm{~d}\end{array}$ & $\begin{array}{l}\text { thrombus } \\
\text { aspiration, } \\
\text { thrombolysis } \\
\text { with urokinase } \\
\text { and heparin, } \\
50 \text { mg aspirin } \\
\text { per day }\end{array}$ & $\begin{array}{l}\text { AVP II; } \\
4 \mathrm{~mm}\end{array}$ & yes & no & $\begin{array}{l}\text { died } 21 \text { days after } \\
\text { intervention due to } \\
\text { pneumonia and re- } \\
\text { spiratory failure. } \\
\text { During follow-up no } \\
\text { AVP/puncture tract- } \\
\text { related complica- } \\
\text { tions }\end{array}$ \\
\hline
\end{tabular}

In patients \# $1, \# 2$, and \# 4 the AVP was positioned within the tip of the sheath. Then the sheath was pulled back carefully. Contrast medium was injected through the sheath to document the position of the tip of the sheath within the portal or splenic vein or the transparenchymal puncture tract. Contrast medium that extended to the central veins or through the puncture tract to the perihepatic or perisplenic space helped to determine the position of the sheath within the puncture tract, in particular to determine the distance between the tip of the sheath and the hepatic or splenic capsule. After suiting the AVP at the intended closure site, the sheath was pulled back while fixing the AVP in position. Contrast medium was injected through the sheath to verify the correct position of the AVP. Then the AVP was released and the lock wire (patients \# 1, \# 3, and \# 5) and the sheath were carefully removed.

In patients \# 3 and \# 5 a 6 French guiding catheter (Guider Softip, Boston Scientific, Plymouth, MN, USA) was used in addition for precise AVP placement. The AVP-loaded catheter was placed in the central part of the liver or spleen. The sheath was pulled back until the tip of the sheath was suited at a subcapsular position about $1 \mathrm{~cm}$ medial to the hepatic or splenic capsule. The guiding catheter was pulled back and the AVP was released at the intended closure site.

To enable precise AVP placement, the C-arm of the angiography unit was positioned so that the view direction was orthogonal to the transparenchymal puncture tract. In patient \# 5, sonography was used in addition to fluoroscopy to control the placement of the AVP. The AVP was clearly visible on ultrasound as a strongly echogenic object within the subcapsular intrasplenic puncture tract. Using both fluoroscopic as well as sonographic guidance helped to determine the definite position of the AVP within the puncture tract.

After removal of the sheath, a patch was applied to the cutaneous puncture site. Ten minutes later sonography of the upper abdomen was performed to rule out bleeding. Four hours later another sonographic control and control of the hemoglobin level were carried out. Peri-interventional antimicrobial therapy was given in patients \# 3 and \# 5 . 

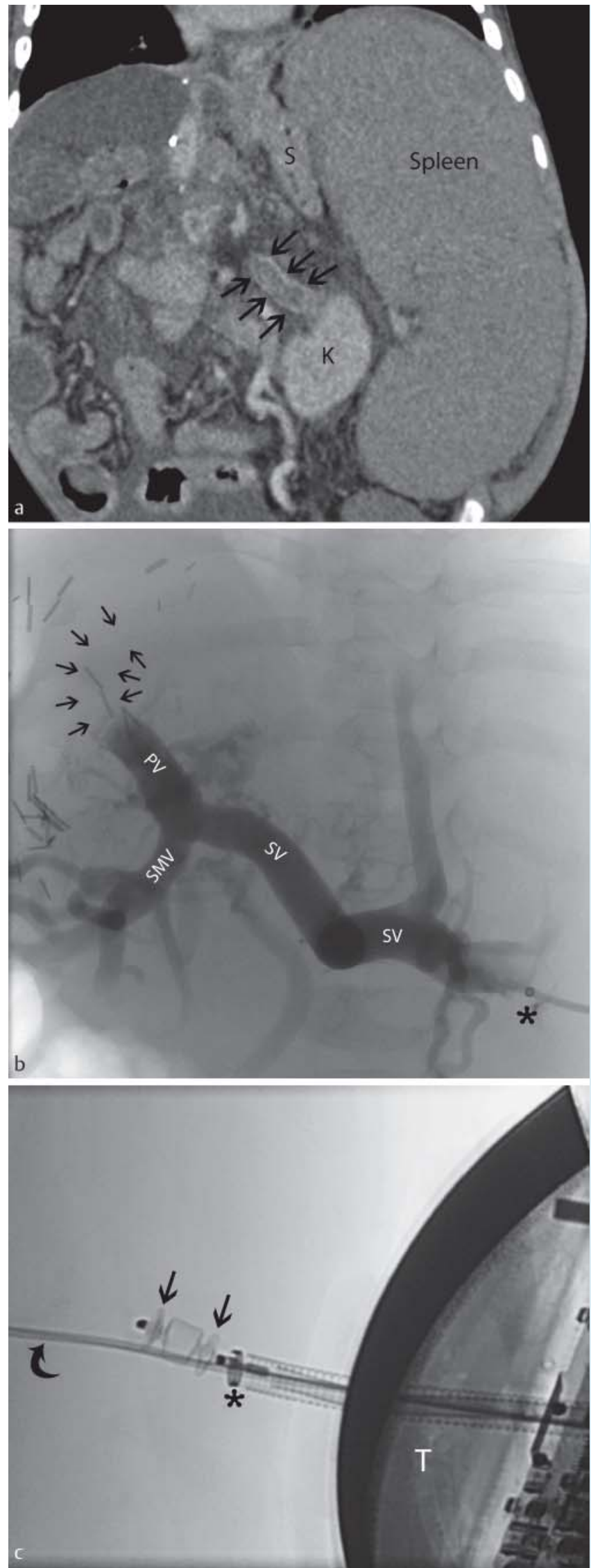

Fig. 1 3-year-old boy (patient \# 5) with biliary atresia, status post orthotopic transplantation of a left-lateral-segment liver graft, and currently secondary sclerosing cholangitis, portal hypertension and splenomegaly. a Coronal reconstruction of contrast-enhanced computed tomography displayed extensive thrombosis of the splenic vein (delineated by arrows) as well as some thrombi within the portal vein (not shown). K, left kidney; S, stomach. b Despite heparin therapy, the thrombosis was progressive sonographically and ascites was accumulating. Hence, two days after computed tomography percutaneous intervention was carried out. The tip of an Accustick Introducer system (asterisk; Boston Scientific, Natick, MA, USA) was placed within an intrasplenic vein via transsplenic access. After contrast material injection via the introducer system, the splenic vein (SV) as well as the proximal part of the portal vein (PV) were patent without identifiable residual thrombi. However, the distal part of the portal vein (its course is displayed by arrows) was not contrasted due to extensive thrombi which might have moved from the splenic vein to this site. SMV, superior mesenteric vein. c After transsplenic thrombus aspiration and thrombolysis, the transsplenic puncture tract was embolized using an Amplatzer Vascular Plug II (diameter, $4 \mathrm{~mm}$; arrows). Asterisk, tip of sheath; curved arrow, lock wire; $\mathrm{T}$, ultrasound transducer.

Abb. 1 3-jähriger Junge (Patient \# 5) mit Gallengangsatresie, Z. n. orthotoper Lebertransplantation eines links-lateralen Leberlappens und aktuell sekundär sklerosierender Cholangitis, portaler Hypertension und Splenomegalie. a Eine koronare Rekonstruktion einer Kontrastmittelverstärkten Computertomografie zeigte eine ausgedehnte Thrombose der Vena lienalis (Pfeile) als auch einige Thromben innerhalb der Pfortader (nicht abgebildet). K, linke Niere; S, Magen. b Trotz Heparintherapie stellte sich der Thrombus sonografisch progredient dar und die Aszitesbildung war zunehmend. Folglich wurde zwei Tage nach der Computertomografie eine perkutane Intervention ausgeführt. Die Spitze eines Accustick-Introducer-Systems (Sternchen, Boston Scientific, Natick, Massachusets, USA) wurde über einen transsplenischen Zugang innerhalb einer intrasplenischen Vene platziert. Nach Kontrastmittelinjektion über das Introducer-System zeigten sich sowohl die Vena lienalis (SV) als auch die proximale Pfortader (PV) offen ohne Nachweis residueller Thromben. Der distale Anteil der Pfortader (Verlauf durch Pfeile markiert) kontrastierte sich aufgrund ausgedehnter Thromben, welche sich möglicherweise von der Vena lienalis an diese Stelle verlagerten, nicht. SMV, Vena mesenterica superior. c Nach transsplenischer Thrombusaspiration und Thrombolyse wurde der transsplenische Punktionskanal mittels Amplatzer Vascular Plug II (Durchmesser: 4 mm; Pfeile) embolisiert. Sternchen, Schleusenspitze; gebogener Pfeil, Sicherungsdraht; T, Ultraschallsonde. 

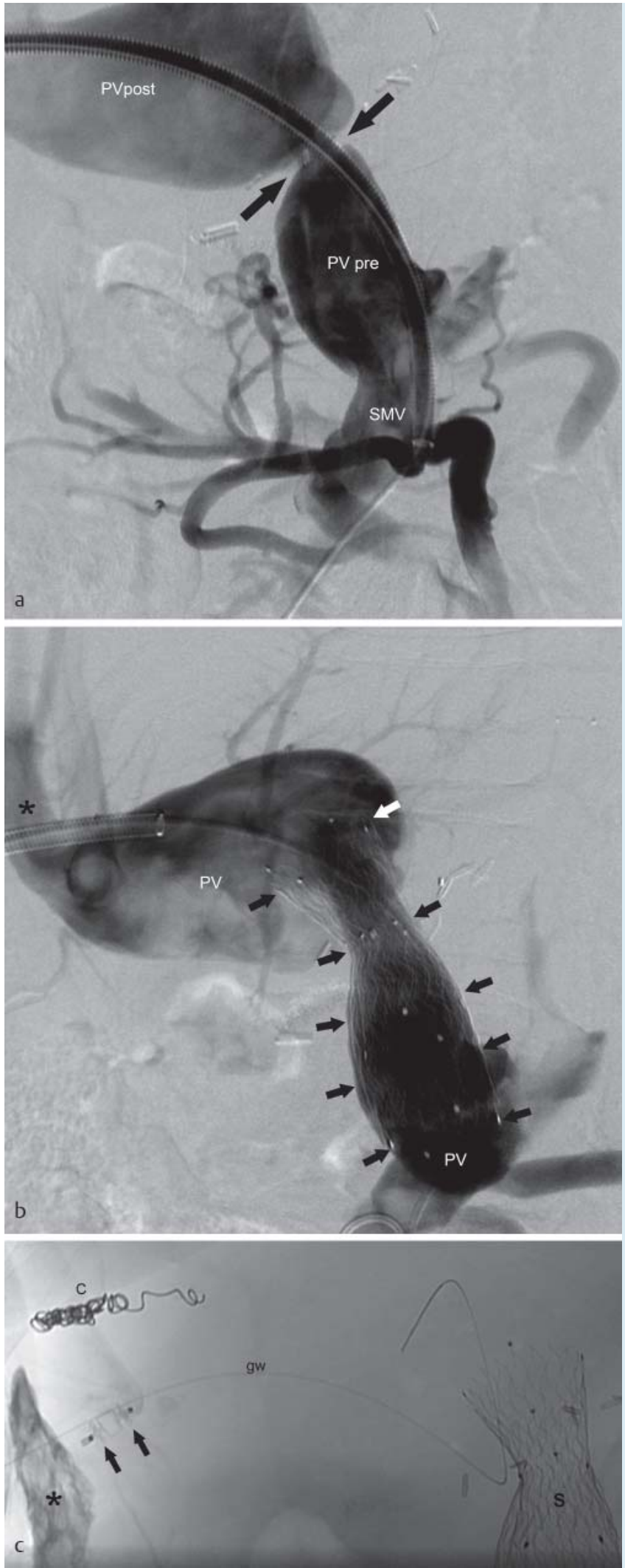

\section{Follow up}

The medical records were evaluated to assess the technical and clinical success of the puncture tract embolization and to assess local or systemic complications related to AVP placement (e.g.,
Fig. 2 70-year-old female (patient \# 1) with biliary cirrhosis and status post liver transplantation. a After percutaneous transhepatic access to the portal vein system, the tip of a sheath was placed in the cranial part of the superior mesenteric vein (SMV). After contrast material (CM) injection via the sheath, digital subtraction angiography displayed high-grade stenosis of the portal vein anastomosis (arrows). PVpre, prestenotic portal vein. PVpost, poststenotic portal vein. b The stenosis was successfully treated by implantation of two overlapping Sinus-XL-Stents ( $22 \mathrm{~mm}$ $\times 40 \mathrm{~mm}$, each, Optimed, Ettlingen, Germany; black and white arrows). PV, portal vein. Asterisk, right portal vein branch. c The transhepatic puncture tract was embolized with an Amplatzer Vascular Plug (AVP) II. Posterior-anterior fluoroscopy displayed the AVP II (diameter, $4 \mathrm{~mm}$; arrows) within the lateral portion of the puncture tract. A guide wire (PT2, Boston Scientific, Natick, Massachusets, USA; gw) was placed within the puncture tract and the portal vein as a lock wire. Asterisk, residual CM which was injected via the sheath prior to AVP II placement and extravasated through the puncture tract to the space lateral to the liver. $S$, the two stents within the portal vein. Three months prior to stent implantation, percutaneous transhepatic balloon angioplasty of the portal vein stenosis was conducted and at that time the transhepatic puncture tract was embolized using microcoils (C).

Abb. 2 Eine 70-jährige Frau (Patient \# 1) mit biliärer Zirrhose und Zustand nach Lebertransplantation. a Nach perkutanem, transhepatischem Zugang in das portalvenöse System wurde die Spitze der Schleuse im kranialen Anteil der Vena mesenterica superior platziert (SMV). Nach Injektion von Kontrastmittel (KM) über die Schleuse zeigte die digitale Subtraktionsangiografie eine hochgradige Stenose der Pfortaderanastomose (Pfeile). PVpre, prästenotische Pfortader, PVpost, poststenotische Pfortader. b Mittels Implantation zweier überlappender Sinus-XL-Stents ( $22 \mathrm{~mm} \times 40 \mathrm{~mm}$, jeweils, Optimed, Ettlingen, Germany; schwarze und weiße Pfeile) wurde die Stenose erfolgreich behandelt. PV, Pfortader. Sternchen, rechter Pfortaderast. c Der transhepatische Punktionskanal wurde mittels Amplatzer Vascular Plug (AVP) II embolisiert. Die posterior-anteriore Fluoroskopie zeigte den AVP II (Durchmesser: $4 \mathrm{~mm}$; Pfeile) innerhalb des lateralen Anteiles des Punktionskanales. Ein Führungsdraht (PT2, Boston Scientific, Natick, Massachusets, USA; gw) wurde als Sicherungsdraht im Punktionskanal und in der Pfortader platziert. Sternchen, KM, welches über die Schleuse vor der AVP-Platzierung injiziert wurde und durch den Punktionskanal in den Raum lateral der Leber austrat. S, die zwei Stents in der Pfortader. Drei Monate vor der Stentimplantation wurde eine perkutane transhepatische Ballonangioplastie der Pfortaderstenose durchgeführt und der transhepatische Punktionskanal mit Mikrocoils embolisiert (C). 

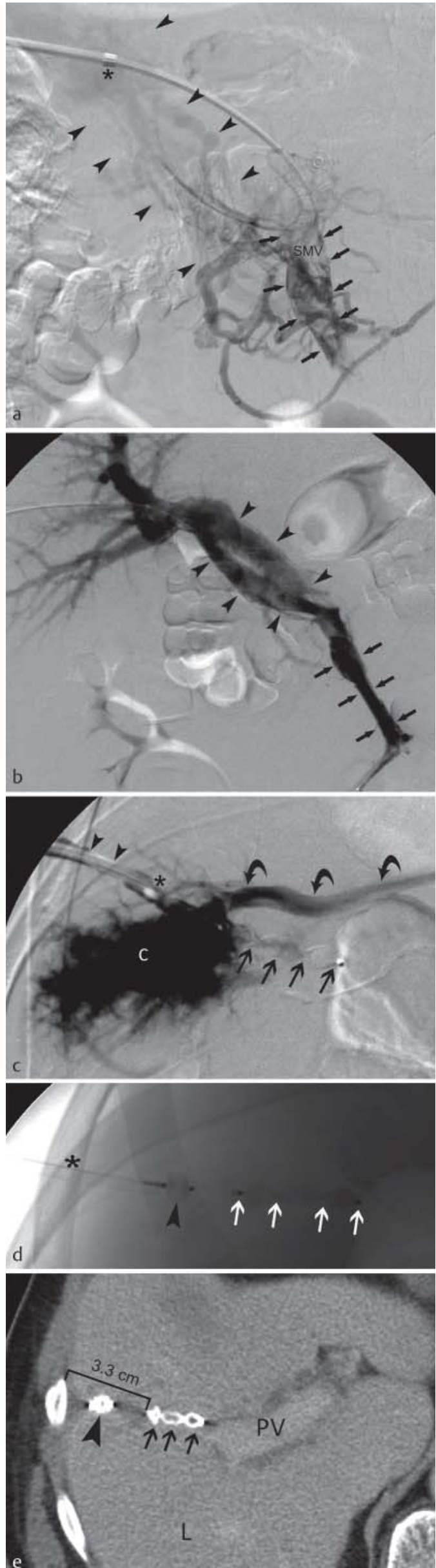

Fig. 3 63-year-old male (patient \# 4) with status post hypernephroma and extensive portal vein thrombosis. a After percutaneous transhepatic access to the portal vein system, the tip of a catheter was positioned in the cranial part of the superior mesenteric vein (SMV). After contrast material injection via the catheter, digital subtraction angiography displayed thrombi within the SMV (arrows) as well as non-enhancement of the main portal vein due to thrombotic occlusion. In addition, digital subtraction angiography showed several faintly contrasted venous collateral channels around the main portal vein (arrowheads) as a correlate of cavernous transformation of the portal vein. Asterisk, tip of the sheath within the portal vein. $\mathbf{b}$ After percutaneous thrombus aspiration and thrombolysis digital subtraction angiography demonstrated a patent SMV (arrows) as well as a patent main portal vein with residual wall-adherent thrombi (arrowheads). c The transhepatic puncture tract was embolized using an Amplatzer Vascular Plug (AVP) II (diameter, $8 \mathrm{~mm}$; arrows). After contrast material injection via the sheath (asterisk, tip of sheath) posterior-anterior digital subtraction angiography demonstrated brisk opacification of a hepatic vein (curved arrows) providing evidence for a fistula between the puncture tract lateral to the implanted AVP II and a hepatic vein. Arrowheads, lateral portion of the puncture tract. C, contrast material extending to the adjacent hepatic parenchyma. d A second AVP II (diameter, $6 \mathrm{~mm}$; black arrowhead) was inserted into the intrahepatic puncture tract lateral to the fistula. Asterisk, delivery wire of the AVP II; arrows, primarily implanted AVP. e A contrastenhanced computed tomography delineates the position of the AVPs II within the liver (L). The distance between the lateral edge of the primarily implanted AVP II (arrows) and the liver capsule was $3.3 \mathrm{~cm}$. Arrowhead, secondarily inserted AVP II. PV, portal vein.

Abb. 3 Ein 63-jähriger Mann (Patient \# 4) mit Zustand nach Hypernephrom stellte sich mit einer ausgedehnten Pfortaderthrombose vor. a Nach perkutan-transhepatischem Zugang in das Pfortadersystem wurde die Spitze des Katheter im kranialen Anteil der Vena mesenterica superior (SMV) positioniert. Nach Injektion von Kontrastmittel über den Kathter zeigte die digitale Subtraktionsangiografie thrombotisches Material innerhalb der SMV (Pfeile) sowie eine ausbleibende Kontrastierung des Pfortaderhauptstammes als Ausdruck einer thrombotischen Okklusion. Zusätzlich waren in der Angiografie mehrere flau kontrastierte venöse Kollateralen um den Pfortaderhauptstamm als Korrelat einer kavernösen Transformation abgrenzbar (Pfeilspitzen). Sternchen, Spitze der Schleuse innerhalb der Pfortader. b Nach perkutaner Thrombusaspiration und Thrombolyse zeigte die Angiografie eine offene SMV (Pfeile) sowie einen offenen Pfortaderhauptstamm mit residuellen, wandadhärenten Thromben (Pfeilspitzen). c Der transhepatische Punktionskanal wurde mittels Amplatzer Vascular Plug (AVP) II (Durchmesser: 8 mm; Pfeile) embolisiert. Nach Kontrastmittel-Injektion über die Schleuse (Sternchen, Schleusenspitze) zeigte die posterior-anteriore digitale Subtraktionsangiografie eine rasche Kontrastierung einer Lebervene (gebogene Pfeile) als Nachweis einer Fistel zwischen dem Punktionskanal lateral des implantierten AVP und einer Lebervene. Pfeilspitzen, lateraler Anteil des Punktionskanales. C, Kontrastmittel, welches in das angrenzende Leberparenchym austrat. d Ein zweiter AVP II (Durchmesser: $6 \mathrm{~mm}$; schwarze Pfeilspitze) wurde in den intrahepatischen Punktionskanal lateral der Fistel eingebracht. Sternchen, Trägerdraht des AVP. Pfeile, primär eingebrachter AVP. e Die axiale Rekonstruktion einer Computertomografie zeigte die Lage der AVPs II innerhalb der Leber (L). Der Abstand der lateralen Begrenzung des primär eingebrachten AVP (Pfeile) zur Leberkapsel betrug 3,3 cm. Pfeilspitze, sekundär eingebrachter AVP. PV, Pfortader. 

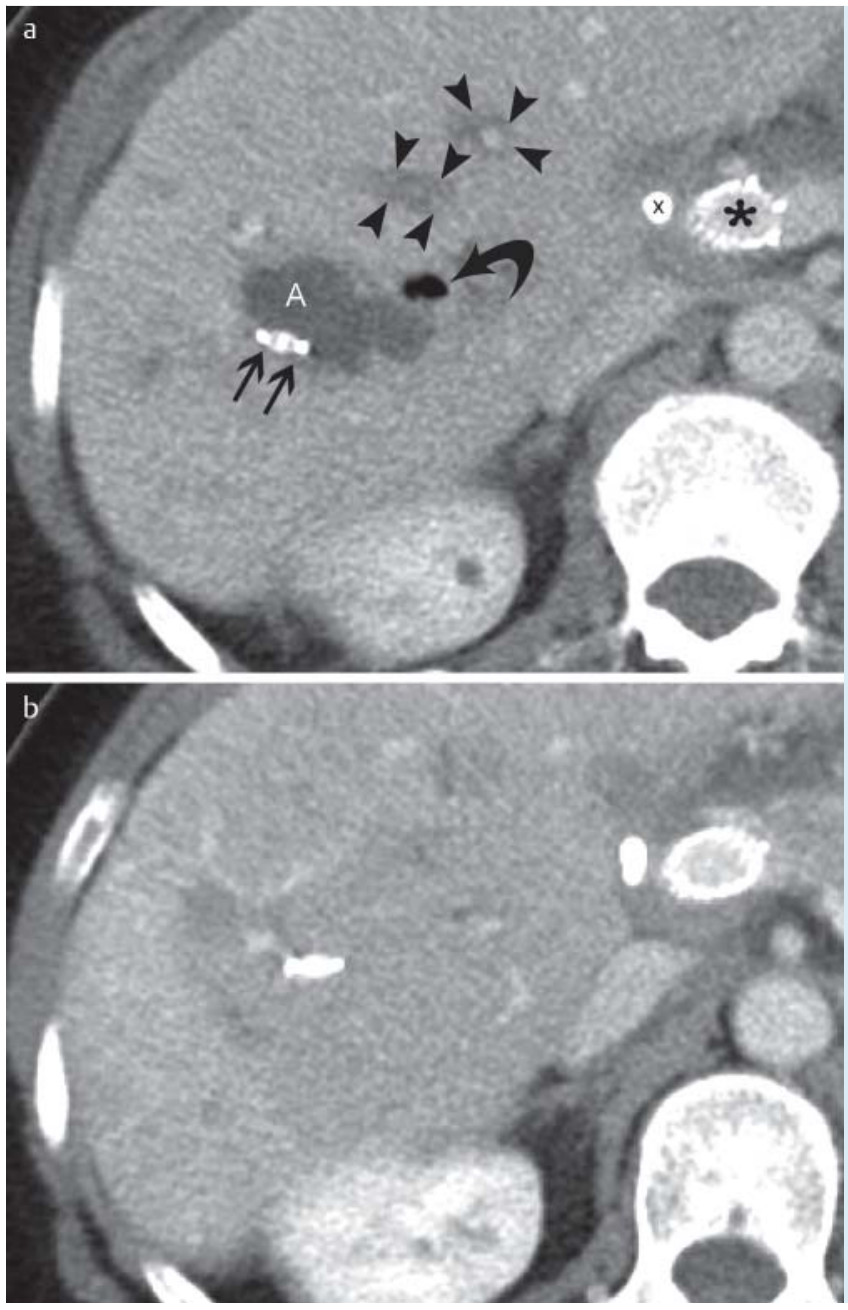

\section{Results}

$\nabla$

Stenting of portal vein stenoses (patients \# 1 and \# 2) as well as thrombus aspiration and thrombolysis of portal vein thrombosis (patients \# 3-5) were carried out technically successfully (residual stenosis $<30 \%$ ) in all five patients. In three cases the transhepatic or transsplenic puncture tract was embolized by using one AVP II (diameter, 4 mm; patients \# 1, \# 3, \# 5; • Fig. 1, 2), in one case by using one AVP IV (patient \# 2; $\odot$ Fig. 4), and in one case (patient \# 4) by using two AVPs II (diameter, 8 and $6 \mathrm{~mm}$; - Fig. 3). In the latter patient (patient \# 4) a fistula between the puncture tract lateral to the primarily implanted AVP II (diameter, $8 \mathrm{~mm}$ ) and a hepatic vein was identified by contrast material injection. Hence, a second AVP II (diameter, $6 \mathrm{~mm}$ ) was placed within the intrahepatic puncture tract lateral to the fistula. In all patients embolization with an AVP was relatively easy and fast to perform and technically successful. There was no case of immediate post-interventional bleeding, bleeding from the puncture site during follow-up or dislocation of the AVP.

During a median follow-up of 14 months (range, 21 days to 21 months), there was one complication related to AVP placement: six days after embolization of the transhepatic puncture tract with an AVP IV, patient \# 2 presented at the institutional emergency department with jaundice (total serum bilirubin: $12.4 \mathrm{mg} / \mathrm{dl}$ ) as well as increased serum C-reactive protein $(15.3 \mathrm{mg} / \mathrm{dl})$. Three days later contrast-enhanced computed tomography depicted a focal hypodense liver lesion around the AVP ( $\bullet$ Fig. 4a). Microbiolo-
Fig. 4 47-year-old female (patient \# 2) with metastatic mucinous adenocarcinoma of the appendix presented with portal vein stenosis due to tumor compression. After percutaneous stenting of the portal vein, the intrahepatic puncture tract was embolized using an Amplatzer Vascular Plug (AVP) IV (diameter, $4 \mathrm{~mm}$ ). a Nine days later contrast-enhanced computed tomography revealed a focal liver abscess (A) adjacent to the AVP (arrows). Curved arrow, air entrapment within the abscess. Arrowheads, augmented fluid retention circular around branches of the portal vein, presumably related to insufficient lymph drainage due to tumorous compression of the lymphatic vessels at the liver hilum. ${ }^{*}$, stent within the portal vein. $x$, stents within the common hepatic duct. b After percutaneous drainage of the abscess and antimicrobial therapy, contrast-enhanced computed tomography performed two months after AVP placement revealed complete resolution of the abscess.

Abb. 4 47-jährige Frau (Patient \#2) mit metastasiertem muzinösem Adenocarcinom der Appendix vermiformis stellte sich mit einer durch eine Tumorkompression hervorgerufene Pfortaderstenose vor. Nach perkutaner Stentangioplastie der Pfortader wurde der intrahepatische Punktionskanal mittels Amplatzer Vascular Plug (AVP) IV (Durchmesser: $4 \mathrm{~mm}$ ) embolisiert. a Neun Tage später wurde in einer Kontrastmittel-verstärkten Computertomografie ein fokaler Leberabszess (A) angrenzend an den AVP (Pfeile) nachgewiesen. Gebogener Pfeil, Lufteinschluss innerhalb des Abszesses. Pfeilspitzen, vermehrte Flüssigkeitsansammlung zirkulär um intrahepatische Pfortaderäste, mutmaßlich Folge einer insuffizienten Lymphdrainage bei tumoröser Kompression der Lymphgefäße im Leberhilus. *, Stent innerhalb der Pfortader. x, Stents innerhalb des Ductus choledochus. b Nach perkutaner Abszessdrainage und Durchführung einer antibiotischen Therapie war in einer, zwei Monate nach AVP-Implantation durchgeführten Computertomografie kein Abszess mehr nachweisbar.

gical testing of fluid aspirated from the lesion confirmed a liver abscess with beta-hemolytic streptococci. By antimicrobial therapy (Amoxicillin $50 \mathrm{mg}$ and Clavulanic acid $125 \mathrm{mg}, 1-0-1,15$ days) as well as percutaneous drainage of the abscess for one week, the abscess was successfully treated. Contrast-enhanced computed tomography performed two months after AVP placement revealed complete resolution of the abscess ( $\bullet$ Fig. 4 b).

In patients \# 1-4 follow-up computed tomography scans of the upper abdomen were carried out for other reasons. The distance between the lateral edge of the AVP and the liver capsule was $1.3 \mathrm{~cm}, 3.5 \mathrm{~cm}$ and $1.2 \mathrm{~cm}$ in patients \# 1 , \#2 and \# 3, respectively ( $\bullet$ Fig. 2,4 ). In patient \# 4 the distance between the lateral edge of the AVPs and the liver capsule was $3.3 \mathrm{~cm}$ and $0.8 \mathrm{~cm}$ for the primarily and secondarily implanted AVPs, respectively (๑ Fig. 3). No AVP dislocation was detected.

\section{Discussion}

The percutaneous transhepatic approach constitutes a widely accepted access to the portal vein system $[2,4,6]$. However, this access is associated with minor complications like transient pain at the puncture site or mild hypotension as result of vasovagal reaction [9] as well as major complications like bleeding, hemobilia, pseudoaneurysms and infection $[3,10]$. Bleeding from the puncture tract is usually of a venous origin and most likely a result of 
blood running from the punctured portal vein through the puncture tract into the peritoneal cavity.

In order to prevent post-interventional bleeding from the puncture tract 1) it is recommended to puncture the intrahepatic portal vein system as peripherally as possible (in this way the risk of arterial bleeding is minimized), and 2) embolization of the puncture tract has been performed, e. g. by cylinders of collagen, coils, N-butyl cyanoacrylate, Gelfoam and Gelfoam cubes [1 - 5, 7]. In several studies there were no postinterventional bleeding complications $[1,3,11]$, even when the puncture tract was not embolized [11].

However, in other studies bleeding complications were reported: 1) Cheng et al. [2] treated ten liver transplant recipients with portal vein stenosis by percutaneous transhepatic stenting. One patient whose puncture tract was sealed by Gelfoam cubes presented with a hemothorax two hours after intervention. The hemothorax was successfully treated with chest tube drainage. In the remaining nine patients the puncture tract was successfully embolized using metallic coils and N-butyl cyanoacrylate. 2) Ko et al. [4] treated nine liver transplant recipients with portal vein stenosis by percutaneous transhepatic stenting. The puncture tract was embolized with coils in any case. Two patients presented with post-interventional bleeding resulting in hemoperitoneum requiring surgical ligation of the puncture tract. At our institution a patient in whom percutaneous portal vein intervention was performed via a 4 French sheath suffered from post-interventional bleeding requiring emergent surgical ligation of the puncture tract despite embolization of the transhepatic puncture using Gelfoam bars.

In the case of transsplenic portal vein access, hemorrhage from the splenic puncture tract and/or intrasplenic hematomas can occur in particular in patients with portal hypertension, splenomegaly, and thrombocytopenia [8]. Gong et al. [12] performed percutaneous transsplenic embolization of esophageal and gastric varices using 5 French sheaths in 18 patients. Despite embolization of the puncture tract with Gelfoam and coils, erythrocyte counts decreased in all patients after the procedure, five patients required blood transfusion, and two patients experienced hemoperitoneum. Chu et al. [8] performed transsplenic portal vein interventions using 4-9 French sheaths in nine patients. The transsplenic puncture tract was embolized using coils and N-butyl cyanoacrylate. In all nine patients, there was no occurrence of procedure-related or bleeding complications.

In the present study five relatively large bore transhepatic and transsplenic puncture tracts were successfully embolized with AVPs. In addition, in patient \# 5, a 3-year old boy, it was possible to place the AVP within the relatively short transsplenic puncture tract precisely and safely at a subcapsular position using fluoroscopic and sonographic guidance.

It seems favorable to place the AVP within the puncture tract at a subcapsular site with a distance between the AVP and the hepatic or splenic capsule of $1.5 \mathrm{~cm}$ and $1.0 \mathrm{~cm}$ in adults and children, respectively. This approach was shown to effectively embolize the puncture tract (patients \# $1-3$, \# 5). If an AVP is not correctly placed in the first attempt, it can be easily repositioned prior to final release.

As a rare complication of puncture tract embolization, infectious complications can occur. In a study of Kim et al. [3] a local liver abscess emerged in one of 19 patients, although antimicrobial agents were routinely given 24 hours before and for 3 days after the procedure. In our study one patient developed a focal liver abscess adjacent to the AVP. In this patient augmented fluid re- tention around the intrahepatic portal veins was identified on computed tomography which was considered to be a consequence of insufficient lymph drainage due to tumorous compression of the lymphatic vessels at the liver hilum. This impaired lymph drainage might have increased the risk for infection. Another known risk factor for infectious complications of the liver is liver ischemia [13]. In our study population there was no evidence for post-interventional liver ischemia, in particular no stenosis of the hepatic artery and no residual stenosis of the portal vein were identified.

In order to prevent infectious complications, working under sterile conditions is indispensable. In the case of ischemia or impaired lymphatic drainage of the liver or spleen, AVPs should be used with caution. Peri-interventional antimicrobial prophylaxis is recommended, in particular in patients with an increased risk for infectious complications.

Further disadvantages of using AVPs for puncture tract embolization are the possibility of AVP dislocation, e.g. into the peritoneal cavity, a foreign body that remains in situ, relatively high costs, and that an intact coagulation system is required for successful embolization.

In summary, in several studies bleeding complications from transhepatic and transsplenic puncture tracts were reported despite embolization of the tract with various embolic agents including collagen, coils, Gelfoam, and glue. The results of our small series indicate that AVPs are suited to embolize large bore and/or short transhepatic and transsplenic puncture tracts effectively, safely, and precisely. To prevent infectious complications, peri-interventional antimicrobial prophylaxis is recommended.

\section{Clinical Relevance \\ $\nabla$}

- Embolization of transhepatic and transsplenic puncture tracts with AVPs is feasible

- Large and/or short puncture tracts can be effectively embolized with AVPs

- The risk of infectious complications has to be considered

\section{Acknowledgments}

$\nabla$

The authors express their gratitude to Dietlinde Ulsperger for editing the figures

\section{References}

1 Adani GL, Baccarani U, Risaliti A et al. Percutaneous transhepatic portography for the treatment of early portal vein thrombosis after surgery. Cardiovasc Intervent Radiol 2007; 30: 1222-1226

2 Cheng Y, Ou H, Tsang LL et al. Vascular stents in the management of portal venous complications in living donor liver transplantation. Am J Transplant 2010; 10: 1276-1283

3 Kim KR, Ko G, Sung K et al. Percutaneous transhepatic stent placement in the management of portal venous stenosis after curative surgery for pancreatic and biliary neoplasms. Am J Roentgenol 2011; 196: W446 W450

$4 \mathrm{Ko} G$, Sung $K$, Yoon $\mathrm{H}$ et al. Early posttransplantation portal vein stenosis following living donor liver transplantation: percutaneous transhepatic primary stent placement. Liver Transpl 2007; 13: 530-536

5 Wang JF, Zhai RY, Wei BJ et al. Percutaneous intravascular stents for treatment of portal venous stenosis after liver transplantation: midterm results. Transplant Proc 2006; 38: 1461 - 1462 
6 Wei B, Zhai R, Wang J et al. Percutaneous portal venoplasty and stenting for anastomotic stenosis after liver transplantation. World J Gastroenterol 2009; 15: 1880 - 1885

7 Heiss $P$, Grothues D, Loss $M$ et al. Akute Pfortaderthrombose bei einem 5-jährigen Kind: Rekanalisierung mittels perkutaner Thrombenaspiration und Thrombolyse. Fortschr Röntgenstr 2013; 185: 563 -566

$8 \mathrm{Chu} \mathrm{HH}$, Kim H, Jae HJ et al. Percutaneous transsplenic access to the portal vein for management of vascular complication in patients with chronic liver disease. Cardiovasc Intervent Radiol 2012; 35: 1388 1395

9 Bravo AA, Sheth SG, Chopra S. Liver biopsy. N Engl J Med 2001; 344: $495-500$
10 Piccinino F, Sagnelli E, Pasquale G et al. Complications following percutaneous liver biopsy. A multicentre retrospective study on 68,276 biopsies. J Hepatol 1986; 2: 165-173

11 Funaki B, Rosenblum JD, Leef JA et al. Percutaneous treatment of portal venous stenosis in children and adolescents with segmental hepatic transplants: long-term results. Radiology 2000; 215: 147-151

12 Gong GQ Wang XL, Wang JH et al. Percutaneous transsplenic embolization of esophageal and gastrio-fundal varices in 18 patients. World J Gastroenterol 2001; 7: 880-883

13 Tarazov PG, Polysalov VN, Prozorovskij KV et al. Ischemic complications of transcatheter arterial chemoembolization in liver malignancies. Acta Radiol 2000; 41: 156-160 